\title{
Changes in plasma electrolytes, minerals, and hepatic markers of health across the transition period in dairy cows divergent in genetic merit for fertility traits and postpartum anovulatory intervals
}

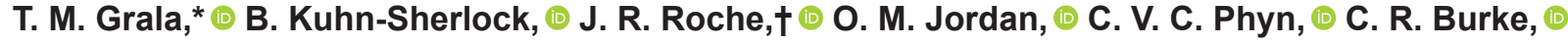 \\ and S. Meier $\odot$ \\ DairyNZ Limited, Hamilton 3240, New Zealand
}

\begin{abstract}
Peripartum metabolism and subsequent reproductive performance of dairy cows are linked, with maladaptation over the transition period associated with poor reproductive success. A herd of seasonal calving, grazing dairy cows was established that differed in their genetic merit for fertility traits. The heifers were produced by a customized mating program to achieve a 10-percentage point divergence in the New Zealand fertility breeding value (FertBV) as follows: +5 FertBV (POS) versus $-5 \%$ FertBV (NEG), while also limiting divergence in other breeding values, including body weight, body condition score, and milk production. In this study, we aimed to characterize differences in metabolic, mineral, and metabolic stress marker profiles during their first postpartum transition period as primiparous heifers and to examine if animals with longer postpartum anestrous intervals (PPAI; more than $66 \mathrm{~d}$ compared with less than $35 \mathrm{~d}$ ) had greater metabolic dysfunction. Blood was sampled at $-21,-14,-7,0,4,7,10,14,17$, 21,28 , and 35 d relative to calving in 455 primiparous cows and plasma analyzed. The NEG cows had lower concentrations of both plasma nonesterified fatty acids and $\beta$-hydroxybutyrate at $\mathrm{d} 7$ compared with POS cows. Detailed temporal profiling of various metabolic, mineral, and metabolic stress markers was undertaken in a subset of cows $(\mathrm{n}=70)$. Cows were selected retrospectively to create 4 groups in a $2 \times 2$ factorial design with either a POS or NEG FertBV and either a short (19-35 d) or long (66-131 d) PPAI. The NEG cows tended, on average, to have lower nonesterified fatty acids and $\beta$-hydroxybutyrate concentrations compared with POS cows across the transition period. Mean
\end{abstract}

Received May 24, 2021.

Accepted September 27, 2021.

*Corresponding author: Talia.Grala@dairynz.co.nz

$\dagger$ Current address: University of Auckland, Auckland 1010, New Zealand. body weight and body condition score was greatest in NEG cows when compared with the POS cows and an interaction with day demonstrated this only occurred precalving. They also had indications of improved liver health precalving, with higher albumin-to-globulin ratios and lower bilirubin concentrations. Concentrations of aspartate aminotransferase were lower, and the Na-to-Cl ratio was greater in cows with a long versus a short PPAI at d 28 and d 35 after calving, potentially because of cows with a short PPAI (19-35 d) returning to estrous during this time. Magnesium concentrations were lower in NEG cows with a short PPAI from d 21 onwards, indicating NEG cows may metabolically respond to estrous differently than POS cows. The NEG-long PPAI cows had greater gammaglutamyl transferase concentrations from calving until d 28 and lower bilirubin concentrations throughout the transition period. Together, the results demonstrate significant effects of FertBV on peripartum metabolic status. However, most of the markers tested returned to reference intervals within $4 \mathrm{~d}$ after calving or remained within those intervals for the whole transition period, indicating relatively minor biological effects of FertBV on transition period adaptation. The profound differences in reproductive performance among the groups was not explained by underlying differences in metabolic responses during the transition period.

Key words: estrus, calving, nonesterified fatty acid, anestrous interval

\section{INTRODUCTION}

Previous animal models comparing different strains of Holstein-Friesian cow have demonstrated differences in fertility but have been confounded by variations in body tissue mobilization after calving, genetic selection priorities, and significant milk production differences. In particular, researchers investigating the fertility differences between Holstein-Friesian cows of North American or New Zealand genetic origin often 
report differences in BCS profiles and the degree of somatotropic axis uncoupling along with the greater milk production in North American cows as reasons for lower fertility compared with the New Zealand strain (Roche et al., 2006; Macdonald et al., 2007; Lucy et al., 2009; McCarthy et al., 2009). However, with increasing focus on greater genetic gain for fertility in breeding programs internationally, more recent research has used animal models that specifically differ in genetic merit for various fertility traits to study how selective breeding can alter reproductive outcomes.

Recently, studies have selected cows based on fertility phenotypes introduced into breeding indices. For example, Veronese et al. (2019a,b) studied more than 1,000 heifers selected for genetic merit for daughter pregnancy rate and heifer conception rate, and reported differences in estrus characteristics, follicle development, and hazard of pregnancy, which demonstrates the ability for improvements in reproductive performance to be made through genetic selection. An Irish research team has published a series of studies investigating phenotypic differences between cows selected on sire and dam calving interval and with a restricted window for their genetic merit for milk production (Cummins et al., 2012; Moore et al., 2014). They reported greater plasma IGF concentrations, greater milk yields across a full lactation, and greater BCS in Fert+ cows than their Fert- counterparts, highlighting that it is possible to select for fertility without negatively affecting milk production (Cummins et al., 2012).

An alternative model was recently established by Meier et al. (2021a,b) using a 500-cow study population divergent in genetic merit for fertility traits based on the New Zealand fertility breeding value (FertBV). The goal was to establish an animal model only divergent in FertBV, by limiting differences in breeding values for BCS, BW, and milk production traits (Meier et al., 2021b). Approximately half the study cows were custom bred to be positive $(+5 \%$; POS $)$ and half negative $(-5 \%$; NEG $)$ for FertBV. Although some effects on BCS profiles and milk production were statistically different, these were relatively minor compared with the marked differences in reproductive parameters between POS and NEG cows (Meier et al., 2021a). In particular, the mean postpartum anestrous interval (PPAI) was longer in NEG cows, and a significantly greater percentage of NEG cows had not resumed estrous cyclicity by 6 wk after the start of seasonal breeding; this resulted in markedly lower submission and pregnancy rates in the pasture-based seasonal calving system (Meier et al., 2021a). Cows that have a prolonged PPAI are particularly disadvantaged in seasonal systems (Senatore et al., 1996), as a shorter time between first ovulation and breeding reduces the probability of insemination and increases the probability of insemination failure (Darwash et al., 1997; Westwood et al., 2002).

The degree of BCS loss and negative energy balance postcalving affects the onset of cyclicity and, therefore, the duration of the PPAI (Opsomer et al., 2000; Roche et al., 2007). Accordingly, increased circulating NEFA concentrations and production of BHB during severe negative energy balance have been associated with longer intervals to first ovulation (Meikle et al., 2004; Wathes et al., 2007; Santos et al., 2009). Greater circulating concentrations of aspartate aminotransferase (AST) and gamma-glutamyl transferase (GGT) have also been reported in cows that had not ovulated by 3 wk postcalving compared with those that had (Kawashima et al., 2016), supporting an important role of liver function in the resumption of estrous. Our studies involved cows that differed in their FertBV as indicated minor BCS differences over the transition period, but there was a wide range of PPAI, especially in NEG cows (Meier et al., 2021b). Therefore, we hypothesized that blood metabolite, minerals and metabolic stress marker profiles during the transition period would be similar among the POS and NEG cows, but may be associated with duration of PPAI.

\section{MATERIALS AND METHODS}

The experiment was conducted at the AgResearch Tokanui Research Farm (Te Awamutu, New Zealand) from June to November 2017. All procedures had prior approval from the Ruakura Animal Ethics committee (\#14200; Hamilton, New Zealand).

\section{Animals}

A group of 494 first-calving, 2-yr-old HolsteinFriesian heifers were considered as candidates for this experiment. Each had been confirmed as pregnant to co-mingled Jersey bulls and were due to start seasonal calving in July 2017. The heifers were either POS or NEG for FertBV and were progeny from a customized breeding program to create a study population divergent in genetic merit for fertility traits. A FertBV of +5 equates to $5 \%$ more daughters calving in the first $42 \mathrm{~d}$ of the calving season, and -5 equates to $5 \%$ fewer daughters calving in the first $42 \mathrm{~d}$ compared with a 0 FertBV. This divergence was estimated to generate a population in the top $15 \%$ and lowest $15 \%$ of fertility breeding values nationally (3.4 is approximately $1 \mathrm{SD}$ in the bull population born from 2009 onward; New Zealand Animal Evaluation Ltd.). The FertBV is estimated using 8 predictor traits that includes 6 
reproductive traits (i.e., submission to breeding rates during first, second, and third lactations and recalving rates during second, third, and fourth lactations in a seasonal system) as well as milk volume in a cow's first lactation and BCS in the cow's first lactation at 60 DIM (New Zealand Animal Evaluation Ltd.). The breeding program restricted breed composition to at least 15/16th Holstein-Friesian and the inbreeding coefficient to $<12 \%$. It also ensured that the expected parent average estimated breeding values for milk volume, fat, protein, BW, and ancestry (\% North American Holstein-Friesian) were within 1 standard deviation. As the FertBV and BCS breeding values are linked, the BCS breeding value was unavoidably higher in the POS group relative to the NEG group (0.07 vs. -0.08 BCS units). Full details of the breeding program and heifer phenotypes are described in Meier et al. (2021a).

\section{Animal Management}

Cows were managed in 2 herds (balanced for expected calving date and FertBV group) and grazed perennial ryegrass and white clover pastures in a rotational manner typical for pasture-based systems in New Zealand. As a result, cows had access to a fresh allocation of pasture twice daily and only returned to the same area when a minimum of 2 leaves had appeared on the majority $(>66 \%)$ of perennial ryegrass (Lolium perenne L.) tillers (approximately 3,000-3,200 $\mathrm{kg}$ of DM/ha in winter and 2,500-3,000 kg of DM/ha in spring; all measurements to ground level). Maize silage was fed to the cows on a feed pad $(2.5 \mathrm{~kg}$ of DM/cow in winter). Magnesium oxide was top dressed on pastures grazed by the nonlactating cows from $21 \mathrm{~d}$ before the planned start of calving until calving was completed. Water troughs were in each paddock so that cows had continual access to water.

\section{Body Weight and BCS}

Body weights $(\mathrm{kg})$ were recorded using static scales (Gallagher) and BCS determined (10-point scale; Roche et al., 2004) every 2 wk at approximately $0900 \mathrm{~h}$ during the precalving period or following a.m. milking when lactating. Cows were also weighed and BCS was assessed as soon as practical after parturition.

\section{Blood and Liver Sampling Regimen}

Blood was withdrawn from the coccygeal vessel into evacuated blood tubes containing lithium heparin (BD Vaccutainers, BD) at $-21(-21.6 \pm 2.42$, mean $\pm \mathrm{SD})$, $-14(-14.0 \pm 2.05),-7(-7.6 \pm 1.73), 0,4,7,10,14$,
$17(17.0 \pm 0.14), 21(21.1 \pm 0.42), 28(28.0 \pm 1.42)$ and $35(35.0 \pm 1.48)$ d relative to calving. Samples were placed in ice water and transported to the laboratory at the end of the sampling day and centrifuged $\left(\right.$ at $4^{\circ} \mathrm{C}$, $1,900 \times g$ for $12 \mathrm{~min}$ ) for plasma separation. Plasma was stored in duplicate aliquots at $-20^{\circ} \mathrm{C}$ until analysis.

A liver biopsy sample was collected from cows $(\mathrm{n}=$ 398 ) at $d 7$ postcalving. Briefly, the skin was shaved and disinfected, and the area through the skin and body wall was anesthetized with $7 \mathrm{~mL}$ of $2 \%$ lignocaine (Lopaine 2\%; lignocaine hydrochloride $20 \mathrm{mg} /$ $\mathrm{mL}$; Ethical Agents). A stab incision was made through the skin in the right 11th intercostal space at the level of the greater trochanter through which a 12-gauge $x$ 20 -cm biopsy needle was inserted into the liver and approximately $200 \mathrm{mg}$ (wet weight) of liver tissue was collected. Samples were stored at $-80^{\circ} \mathrm{C}$ until analysis.

\section{Postpartum Anovulatory Interval Determination}

Milk samples were collected twice-weekly from every animal from $14 \mathrm{~d}$ postcalving until $42 \mathrm{~d}$ of AI was completed during the seasonal breeding period to determine when estrus resumed. The milk was defatted, and progesterone measured in the skimmed samples using a commercial kit (ImmuChem Progesterone Double Antibody RAI; MP Diagnostics) modified by halving the volume of reagents and samples or standards. The average intra-assay CV for the high and low controls was 7.5 and $9.2 \%$, respectively, the average interassay CV for the high and low controls was 11.3 and $12.1 \%$, respectively, and the minimum detectable level was $0.44 \mathrm{ng} / \mathrm{mL}$. The estimated date of first ovulation was defined as when the first of 2 consecutive or 2 of 3 milk samples contained progesterone concentrations of $\geq 0.55 \mathrm{ng} / \mathrm{mL}$ (Meier et al., 2021a,b). The PPAI was the difference between calving date and first ovulation date. Cows whose skim milk progesterone concentrations had not been elevated by the end of the progesterone sample regimen ( $38 \mathrm{~d}$ after the start of breeding) were right-censored, with the censored PPAI as days between calving to the start of breeding $+39 \mathrm{~d}$.

\section{Breeding Management}

The routine mating management policy for the farm was to submit cows for AI to spontaneous estrus based on estrus detection performed by visual observation with the aid of paint applied to the tail-head (Macmillan et al., 1988). The seasonal breeding period was 98 $\mathrm{d}$ and the majority of cows were bred to AI through the entire seasonal breeding period, except for ill cows transiently separated from the main herds into the sick 
group where they were co-mingled with a Hereford bull. During the breeding period, POS and NEG cows were randomly assigned to AI by sires with POS or NEG genetic fertility, respectively, for the first $63 \mathrm{~d}$, followed for a further $21 \mathrm{~d}$ of $\mathrm{AI}$ with short gestation length semen.

Cows not mated in the first $42 \mathrm{~d}$ were examined on d $44 \mathrm{~d}$ after the start of breeding for the presence of a corpus luteum using transrectal ultrasonography with a 5- to 15-MHz probe (SonoScape S6V; Euromed Medical Systems). Those cows without a corpus luteum were synchronized with an intravaginal P4-releasing device (CIDR, Zoetis New Zealand Ltd.) from d -9 to -2 , gonadorelin (Ovurelin $100 \mathrm{mg}$ i.m.; Bomac Laboratories Ltd.) on $\mathrm{d}-9$, and $500 \mathrm{mg}$ of cloprostenol i.m. on $\mathrm{d}-2$ (Ovuprost; Elanco). Cows were bred using AI (d 0) and subsequently on observed estrus.

\section{Experimental Cow Selection}

Of all the cows $(\mathrm{n}=494), 455$ had samples taken over the transition period that were used for plasma NEFA and BHB analyses at $\mathrm{d} 7$ and 14 relative to calving and 398 had samples that were used for liver triacylglyceride (TAG) analysis at d 7. A subset of cows was retrospectively selected for detailed temporal profiling of various metabolic, mineral, and metabolic stress markers across the transition period to determine plasma profile changes associated with FertBV, PPAI, or any interactions. Cows that calved between July 10 and August $31(\mathrm{n}=427)$ were considered eligible. These cows were categorized based on their PPAI length and 157 cows had a PPAI of between 19 to $35 \mathrm{~d}$ (short) or 66 to $100 \mathrm{~d}$ (long). Cows that had not exhibited spontaneous estrus by $42 \mathrm{~d}$ of breeding therefore required a CIDR device to induce estrus were excluded from these groups. Cows were then excluded $(\mathrm{n}=49)$ based on clinical health events such as retained fetal membranes, mastitis before pregnancy, milk fever, calving difficulties, uterine infection, or any other reason a cow was removed from the herd during the first 6 wk of lactation, to increase the likelihood of determining changes in plasma associated with FertBV, PPAI or their interactions. This excluded $27.3 \%$ of the POS FertBV cows, $37.5 \%$ of the NEG FertBV cows, $30.2 \%$ of the short PPAI cows and $32.4 \%$ of the long PPAI cows. Of the remaining eligible cows $(\mathrm{n}=108), 70$ were randomly selected to create 4 groups; POS with a short PPAI of 19 to 35 d (POS S-PPAI; $\mathrm{n}=20)$, POS with a long PPAI of 66 to $100 \mathrm{~d}$ (POS L-PPAI; $\mathrm{n}=20$ ), NEG with a short PPAI of 19 to 35 d (NEG S-PPAI; $\mathrm{n}=14$ ), and NEG with a long PPAI of 66 to $100 \mathrm{~d}$ (NEG L-PPAI; $\mathrm{n}=16$ ).

\section{Analysis of Plasma and Liver Samples}

Metabolite assays were performed using colorimetric techniques at $37^{\circ} \mathrm{C}$ with a Roche Cobas 6000 analyzer (Roche Diagnostics) by Gribbles Veterinary Pathology Ltd. Roche reagent kits were used to measure plasma concentrations of albumin $(\mathrm{g} / \mathrm{L}$; bromocresol green binding at $\mathrm{pH} 4.1)$, AST (IU/L; conversion of 2-oxoglutarate and L-aspartate to L-glutamate and oxaloacetate which then reacts with $\mathrm{NADH}$ to form $\mathrm{NAD}+$ and L-malate), BHB ( $\mathrm{mmol} / \mathrm{L}$; reduction of NAD to NADH during oxidation of d-3-hydroxybutyrate to acetoacetate), bicarbonate $(\mathrm{mmol} / \mathrm{L}$; rate of formation of NAD+ using phosphoenolpyruvate carboxylase), bilirubin ( $\mu \mathrm{mol} / \mathrm{L}$; colorimetric diazomethod), Ca (mmol/L; 5-nitro-5'-methyl-BAPTA complex reactivity with EDTA method), creatine phosphokinase (CPK; IU/L; rate of formation of NADPH using creatine phosphate and ADP), creatinine $(\mu \mathrm{mol} / \mathrm{L}$; enzymatic assay measuring conversion to sarcosine, and liberation of hydrogen peroxide by sarcosine oxidase to form a quinine imine chromogen), glutamate dehydrogenase (GLDH; IU/L; reduction of $\alpha$-ketoglutarate), GGT (IU/L; production of 5-amino2-nitrobenzoate), $\mathrm{Mg}$ ( $\mathrm{mmol} / \mathrm{L}$; xylidyl blue reaction), phosphate (mmol/L; ammonium molybdate with sulfuric acid), total protein (g/L; copper biuret complex), and urea $(\mathrm{mmol} / \mathrm{L}$; urease hydrolysis method based on formation of glutamate and NAD). Plasma globulin was calculated as the difference between total protein and albumin and the albumin-to-globulin ratio was also calculated. Ions $(\mathrm{Na}, \mathrm{K}$, and $\mathrm{Cl}$; $\mathrm{mmol} / \mathrm{L}$ ) were measured by the potentiometric method (ion-selective electrode connected to the Cobas 6000). The anion gap (mmol/L) was calculated by adding $\mathrm{Na}$ and $\mathrm{K}$ and subtracting $\mathrm{Cl}$ and bicarbonate. Plasma NEFA concentrations were measured $(\mathrm{mmol} / \mathrm{L})$ by the acyl-CoA synthetase, acyl-CoA oxidase colorimetric method using the NEFA C Kit (Fujifilm Wako Pure Chemical Corp.). Liver TAG concentrations (\% of wet weight) were determined by Gribbles Veterinary Pathology Ltd. (Hamilton, New Zealand). Briefly, liver samples were weighed and then digested overnight in $20 \%$ potassium hydroxide solution, followed by addition of $10 \% \mathrm{H}_{2} \mathrm{SO}_{4}$ to neutralize the potassium hydroxide, and addition of $1 \%$ CHAPS to solubilize the TAG. The supernatant was then tested photometrically using the Triglycerides GPO-PAP method (TG Kit 11730711, Roche Diagnostics) on the Roche Hitachi Modular-P analyzer as per the manufacturer's instructions. The inter- and intra-assay CV for assays using the modular system were between 0.8 and $5.3 \%$, and 0.5 and $15 \%$, respectively. 


\section{Statistical Analysis}

The statistical analysis package SAS was used for all analyses (Proc mixed, SAS/STAT 15.1; SAS Institute Inc.). Data for creatinine, urea, globulin, bilirubin, GGT, GLDH, BHB, AST, CPK, bicarbonate, NEFA, $\mathrm{Na} / \mathrm{Cl}$ ratio, and liver TAG were $\log _{10}$-transformed before statistical analyses to achieve homogeneity of variance of the residuals. Results are presented as least squares means and the standard error of the difference.

Full Herd. Concentrations of NEFA, BHB at d 7 and 14, and liver TAG at d 7 from the whole herd were analyzed using a 3-way ANOVA for the fixed effects of FertBV (POS $n=242$, NEG $n=213$ ), PPAI length [short $(12-35 \mathrm{~d}, \mathrm{n}=110)$, medium $(36-65 \mathrm{~d}, \mathrm{n}$ $=151)$, long $(66-100 \mathrm{~d}, \mathrm{n}=108)$, or very long $(101-133$ $\mathrm{d}, \mathrm{n}=86)]$, and whether an intravaginal P4-releasing device was required to start estrous (Yes, $\mathrm{n}=110$; No, $\mathrm{n}=345)$. Cow was included as a random effect. The genetic merit of BCS and calving season day (CSD) were included in the model as covariates. The CSD was defined as the number of days from June 1 to actual calving date. Significant effects were declared at $P<$ 0.05 .

Detailed Temporal Profiling Subset. Data were analyzed using a 2-way ANOVA with repeated measures. The genetic merit of BCS and CSD were included in the model as covariates. Fixed effects were FertBV, PPAI group, sample day, and their interaction, with cow as a random effect. The Benjamini-Hochberg method using a false discovery rate of 0.05 on all main and interaction effects corrected the significance level to $P \leq 0.027$. Pairwise comparisons between groups were performed using the Tukey adjustment for multiple comparisons and were declared significant at $P$ $\leq 0.05$.

\section{RESULTS}

\section{Plasma NEFA and BHB and Liver TAG - Full Herd}

From the analysis of the entire data set, plasma BHB concentrations at d 7 and 14 postcalving were lower in NEG cows compared with POS cows (Table 1). A FertBV by PPAI interaction was detected for concentrations of BHB at d 14 (Table 1); NEG cows with a medium PPAI had lower concentrations of BHB compared with POS cows with a medium PPAI $(0.75 \pm 0.095$ vs $1.40 \pm 0.174 \mathrm{mmol} / \mathrm{L} ; \mathrm{LSM} \pm \mathrm{SED} ; P=0.022)$, but there were no significant differences between the other FertBV by PPAI groups. Plasma NEFA concentrations were lower at $\mathrm{d} 7$ postcalving and tended to be lower at d $14(P=0.10)$ in NEG cows. There was also an effect of PPAI group at $d 7$, whereby cows with a long PPAI had lower plasma NEFA than the other PPAI groups,

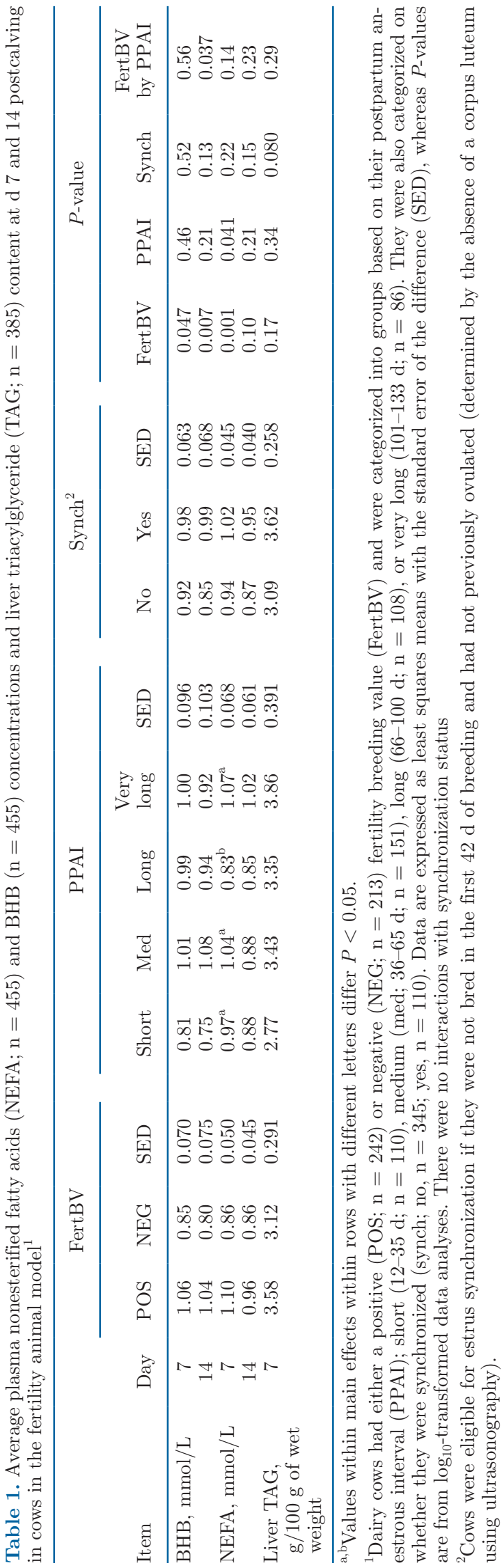

Journal of Dairy Science Vol. 105 No. 2, 2022 
which did not differ from each other (Table 1). Liver TAG concentrations tended $(P=0.080)$ to be greater in cows that required synchronization compared with those that ovulated spontaneously.

\section{Detailed Temporal Profiling Subset}

The main effects of FertBV and PPAI along with their interactions with each other, and with day relative to calving, on BW, BCS, and blood indicators of transition cow health are presented in Tables 2 and 3 . Mean BW and BCS were greater, on average, in NEG compared with POS cows (467 vs. $449 \mathrm{~kg}, 5.0$ vs. 4.9 units; Table 2); however, a FertBV by day interaction for BW indicated that this effect occurred predominantly precalving (Figure 1). There was also a PPAI by day interaction for BCS (Table 2) whereby long PPAI cows had lower BCS than short PPAI cows at $\mathrm{d}-7$, and 0 relative to calving, but the opposite relationship was detected at d 21 (Figure 1).

Both plasma NEFA and BHB concentrations were lower, on average, in NEG cows than the POS cows (Table 2). The significant FertBV by PPAI by day interaction (Table 2) for BHB was due to NEG S-PPAI cows having greater concentrations than NEG L-PPAI cows at d $21(1.22$ vs. $0.61 \mathrm{mmol} / \mathrm{L}, P<0.05)$, but no further differences were detected at other time points $(P>0.05$; results not shown). There was a FertBV by PPAI by day interaction for total protein (Table 2 ); however, the only detectable difference occurred between POS S-PPAI and POS L-PPAI cows at d 4 postcalving $(69.5$ vs. $65.7 \mathrm{~g} / \mathrm{L}, P<0.05$; results not shown). Plasma globulin and the albumin-to-globulin ratio displayed significant FertBV by day interactions (Table 2), which were due to numerically lower $(P=$ $0.11)$ globulin concentrations and a higher $(P=0.04)$ albumin-to-globulin ratio at $\mathrm{d}-7$ precalving in the NEG compared with POS cows (Figure 2). A FertBV by PPAI by day interaction for globulin was also detected (Table 2) but Tukey pairwise comparisons indicated that there were no significant differences $(P>0.05)$ between FertBV by PPAI groups within specific time points (Figure 2). Bilirubin concentrations were lower, on average, in NEG than POS cows over the transition period (Table 2). Concentrations of GGT were greater, on average, in NEG cows, but the FertBV by day and FertBV by PPAI by day interactions (Table 2) indicated that they peaked at calving and were greater in NEG L-PPAI cows compared with POS L-PPAI cows at $\mathrm{d} 0$ and $\mathrm{d} 4(P<0.05$; Figure 3$)$. From d 7 until d 28 postcalving, NEG cows had greater concentrations of GGT compared with POS cows, irrespective of PPAI group (Figure 3). A FertBV by PPAI interaction indi- cated that mean concentrations of GLDH were greater in NEG S-PPAI cows compared with POS S-PPAI and NEG L-PPAI cows (Table 2); however, a PPAI by day interaction was also detected where short PPAI cows had greater GLDH concentrations at $\mathrm{d}-7$ and $\mathrm{d} 4$ than long PPAI cows $(P=0.009$ and $P=0.007$, respectively; Figure 3). Concentrations of AST were also subject to a PPAI by day interaction (Table 2) as cows with short PPAI had greater concentrations at d 28 and d 35 postcalving compared with cows with long PPAI $(P=0.006$ and $P=0.002$, respectively; Figure 3$)$.

There were significant PPAI by day interactions for both $\mathrm{Na}$ and $\mathrm{Cl}$ (Table 3), whereby the short PPAI cows had greater $(P<0.05)$ concentrations at d 10, 21, and 35 postcalving, compared with long PPAI cows (Figure 4). A FertBV by day interaction was also detected for Na (Table 3$)$, with greater $(P<0.05)$ concentrations on $\mathrm{d} 4,21$, and 35 and lower $(P<0.05)$ concentrations on d 28 in NEG cows (Figure 4). The Na-to-Cl ratio was affected by a PPAI by day interaction (Table 3) with a higher ratio in cows that had a long PPAI at d 10, 28, and 35 (Figure $4 ; P=0.029, P=0.05$, and $P<0.001$, respectively). There was a FertBV by PPAI interaction whereby Ca concentrations were lowest in POS L-PPAI cows compared with NEG L-PPAI cows (Table 3). Additionally, a PPAI by day interaction was detected (Table 3), where there were lower Ca concentrations in short PPAI cows at $\mathrm{d}-21(P=0.013)$ but no further differences were observed (results not shown). Interactions with day were detected for FertBV, PPAI and FertBV by PPAI effects on $\mathrm{Mg}$ concentrations (Table 3 and Figure 5). Mg concentrations were lower $(P<0.05)$ in NEG S-PPAI cows than POS S-PPAI cows at d 21 and 35 postcalving (Figure 5). There was a significant FertBV by PPAI by day interaction for creatinine (Table 3), but Tukey pairwise comparisons indicated that there were no significant differences $(P>0.05)$ between groups within specific time points (results not shown). The PPAI by day interaction (Table 3) indicated that urea concentrations were greater in long PPAI cows at $\mathrm{d}-7$ and $\mathrm{d} 0$, but lower at d 17, compared with short PPAI cows $(P=0.019,0.017$, and 0.042 , respectively; Figure 5).

\section{DISCUSSION}

Concentrations of plasma metabolite, mineral and markers of metabolic stress were measured across the transition period in cows with either a POS or NEG FertBV and either a short or long PPAI to determine differences in their response to calving and lactation. We hypothesized that marker profiles during the transition period would be similar among the POS and NEG 
Grala et al.: GENETIC FERTILITY AND THE TRANSITION PERIOD

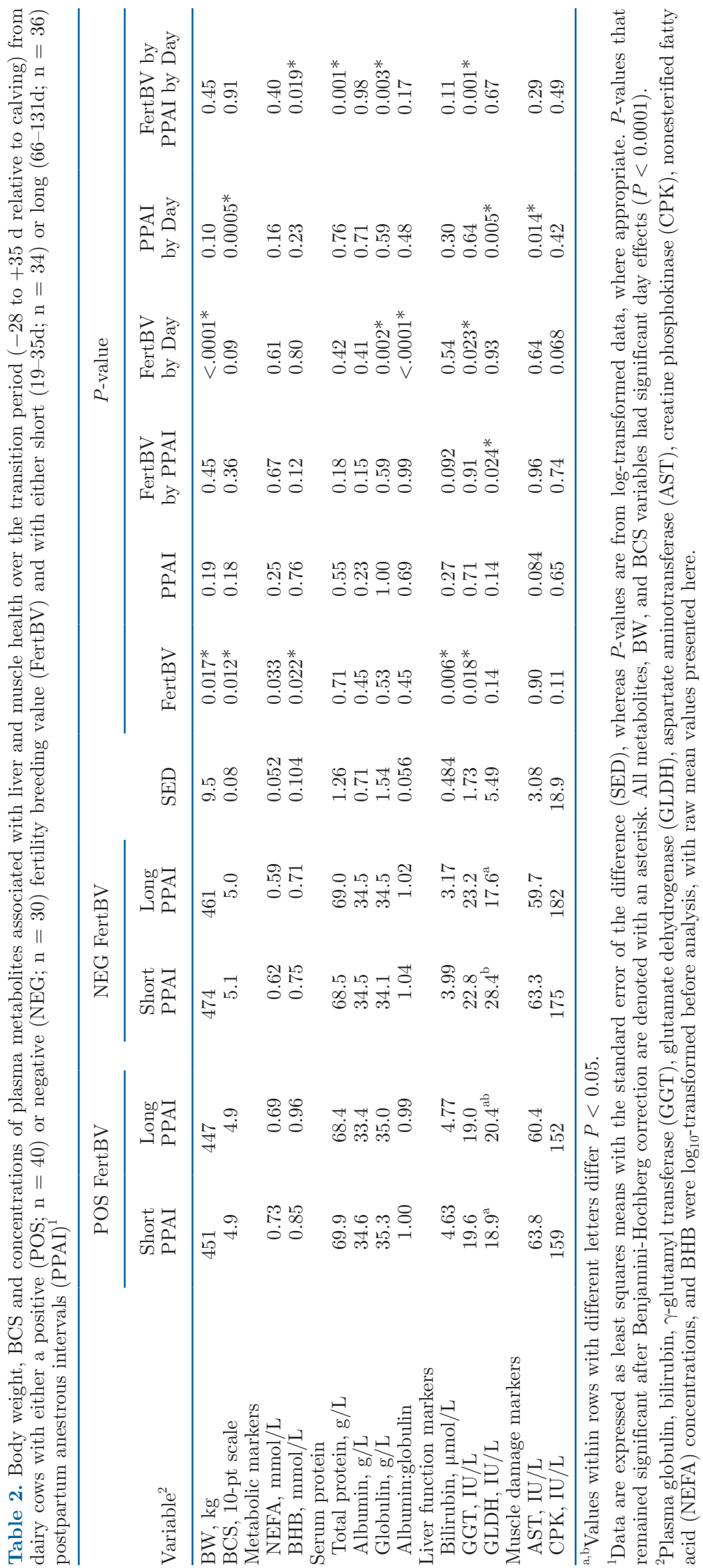




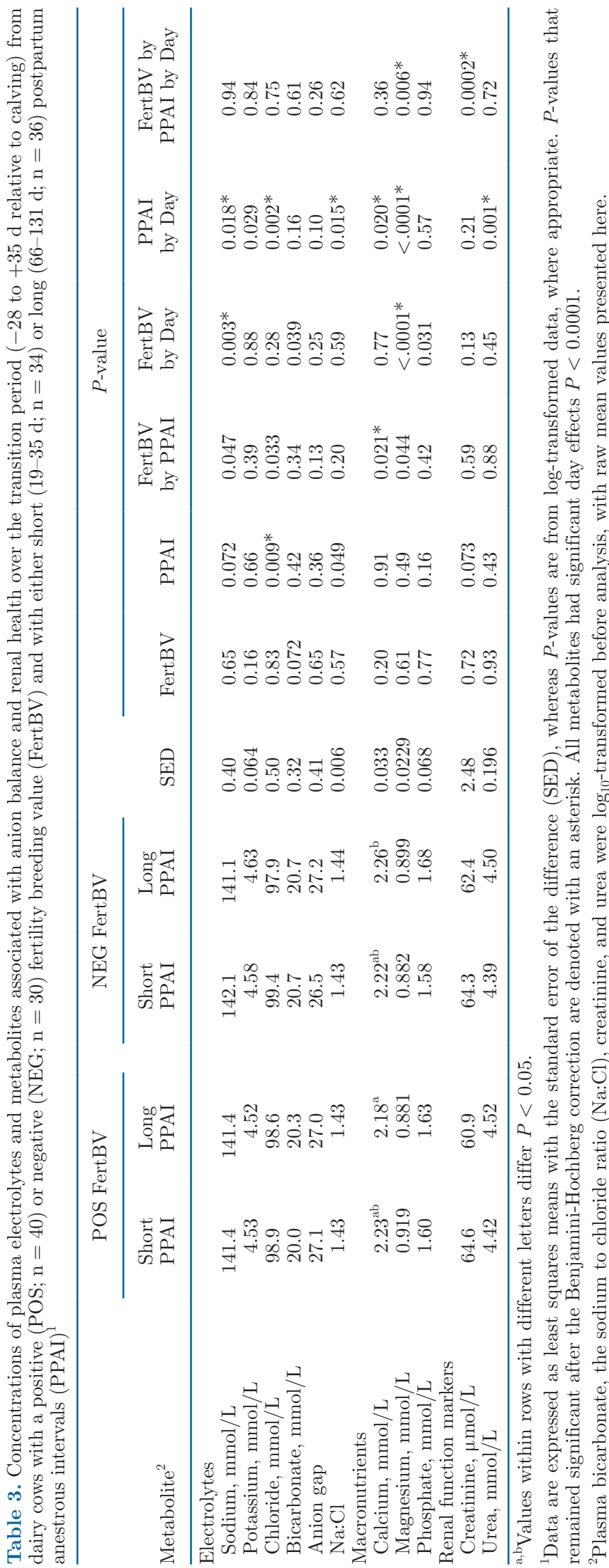

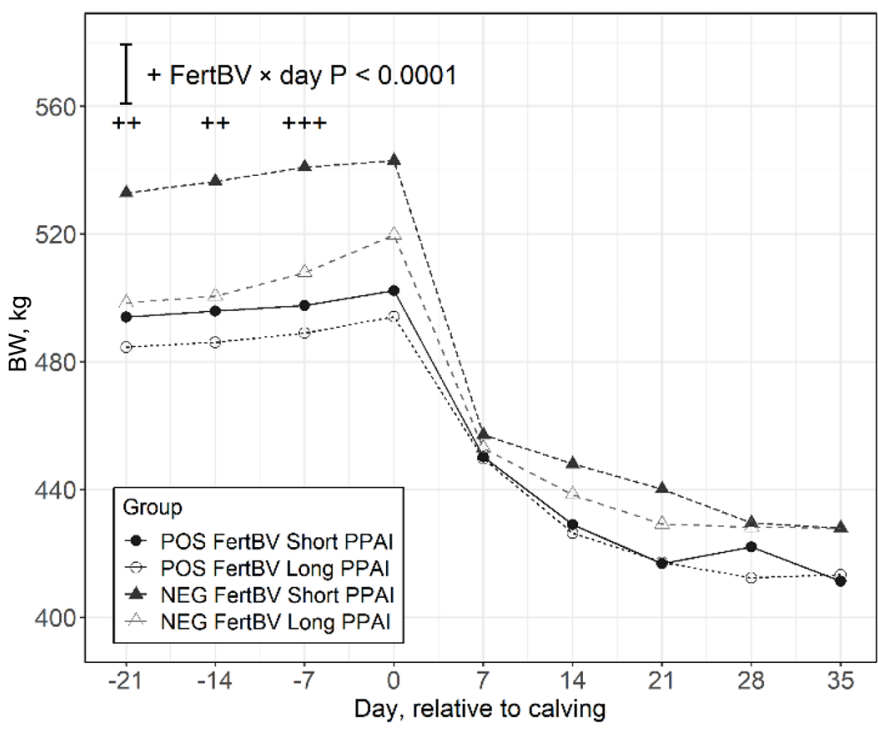

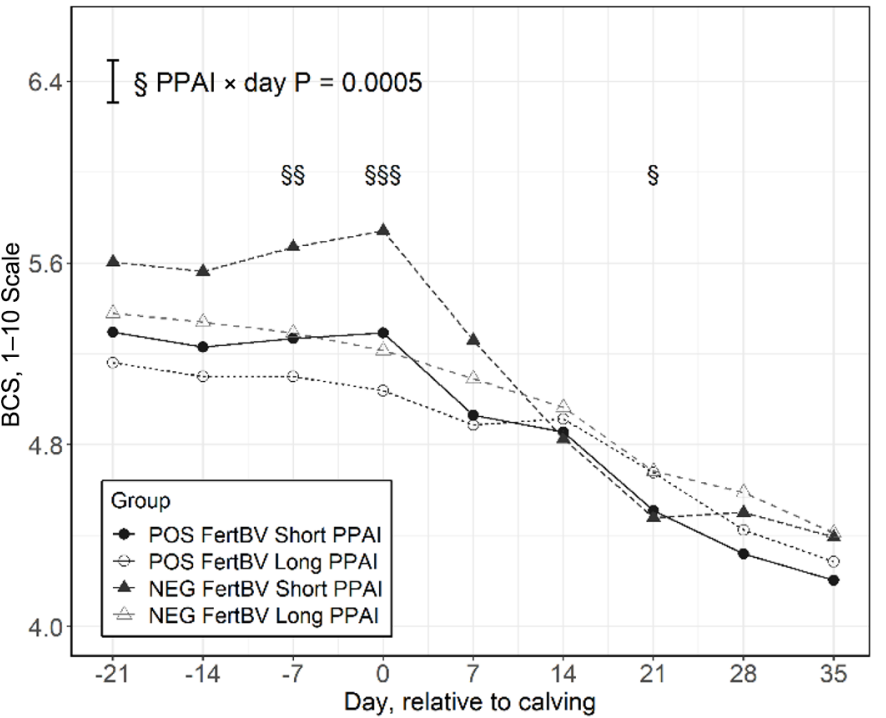

Figure 1. Average BW and BCS from $21 \mathrm{~d}$ precalving to $35 \mathrm{~d}$ postcalving from dairy cows with either a positive (POS) or negative (NEG) fertility breeding value (FertBV) and with either a short (19-35 d) or long (66-131 d) postpartum anestrous interval (PPAI). Error bars represent twice the maximum standard error of the difference. Symbols used for significant effects at a given time point include + for FertBV effects and $\S$ for PPAI effects with 1 symbol $=P<0.05$, 2 symbols $=P<0.01$, and 3 symbols $=P<0.001$.

cows, but may be associated with duration of PPAI. Differences between POS and NEG cows were present, but concentrations in both groups of cows, for the most part, remained within previously reported intervals in Holstein cows over the transition period (Cozzi et al., 2011; Moretti et al., 2017). The majority of the PPAI effects appear to be due to the resumption of estrous in the later weeks, not metabolic dysfunction across calving, which may, in part, be due to profiling a subset of primiparous animals. 

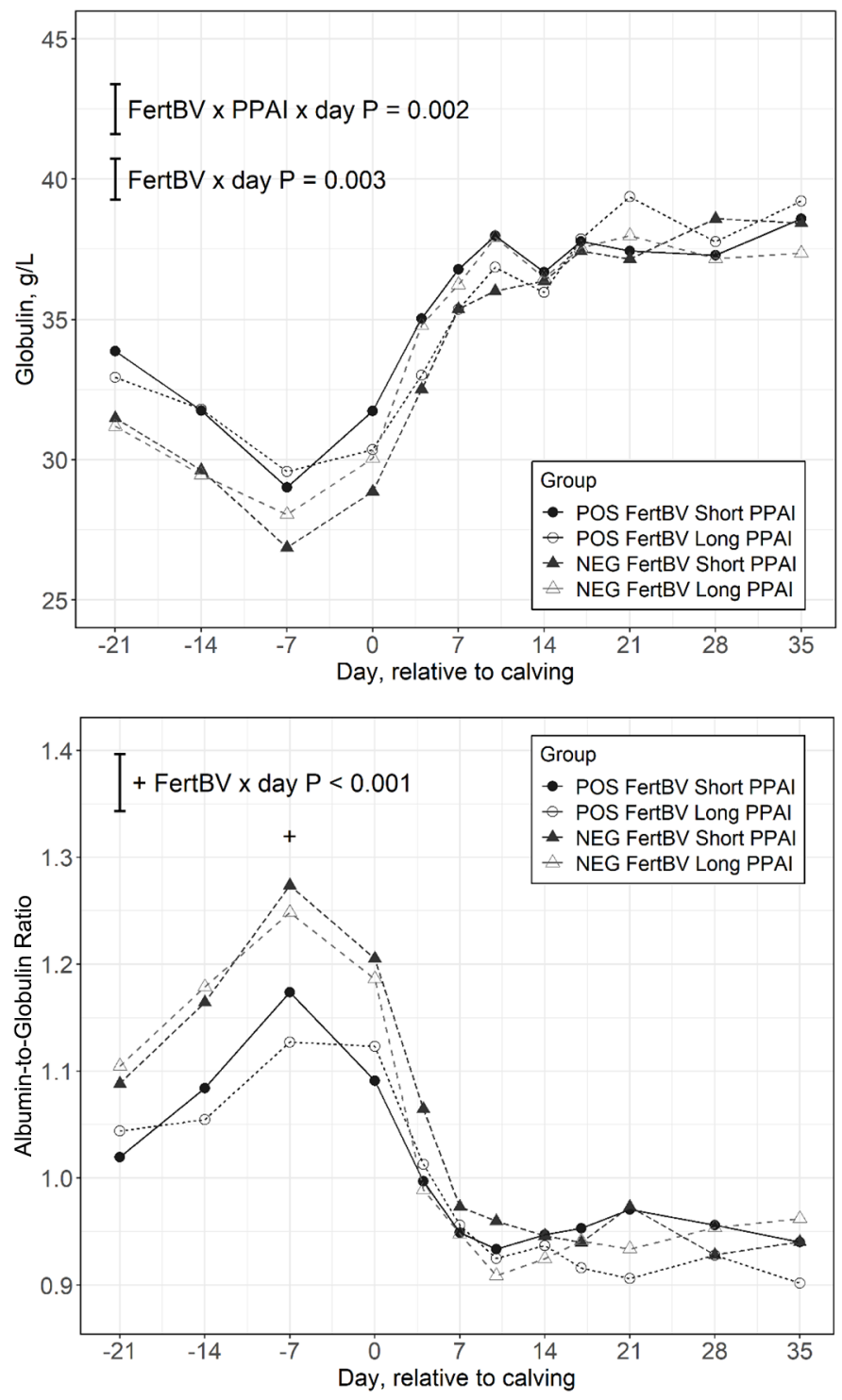

Figure 2. Average daily concentrations of globulin and the albumin-to-globulin ratio from $21 \mathrm{~d}$ precalving to $35 \mathrm{~d}$ postcalving from dairy cows with either a positive (POS) or negative (NEG) fertility breeding value (FertBV) and with either a short (19-35 d), or long (66-131 d) postpartum anestrous interval (PPAI). Error bars represent twice the maximum standard error of the difference. Symbols used for significant effects at a given time point include + for FertBV effects, $\S$ for PPAI effects, and \# for interactions of FertBV and PPAI with 1 symbol $=P<0.05$.

Indicators of negative energy balance were not strongly associated with PPAI length in this study. Although plasma NEFA concentrations in the whole study population at $\mathrm{d} 7$ postcalving were lower in cows with a long PPAI compared with cows of a short, medium, or very long PPAI, the other groups were not different from each other. This effect is inconsistent with previous reports of increased NEFA concentrations (greater than $0.9 \mathrm{mM}$ ) during the first week postcalving being associ-
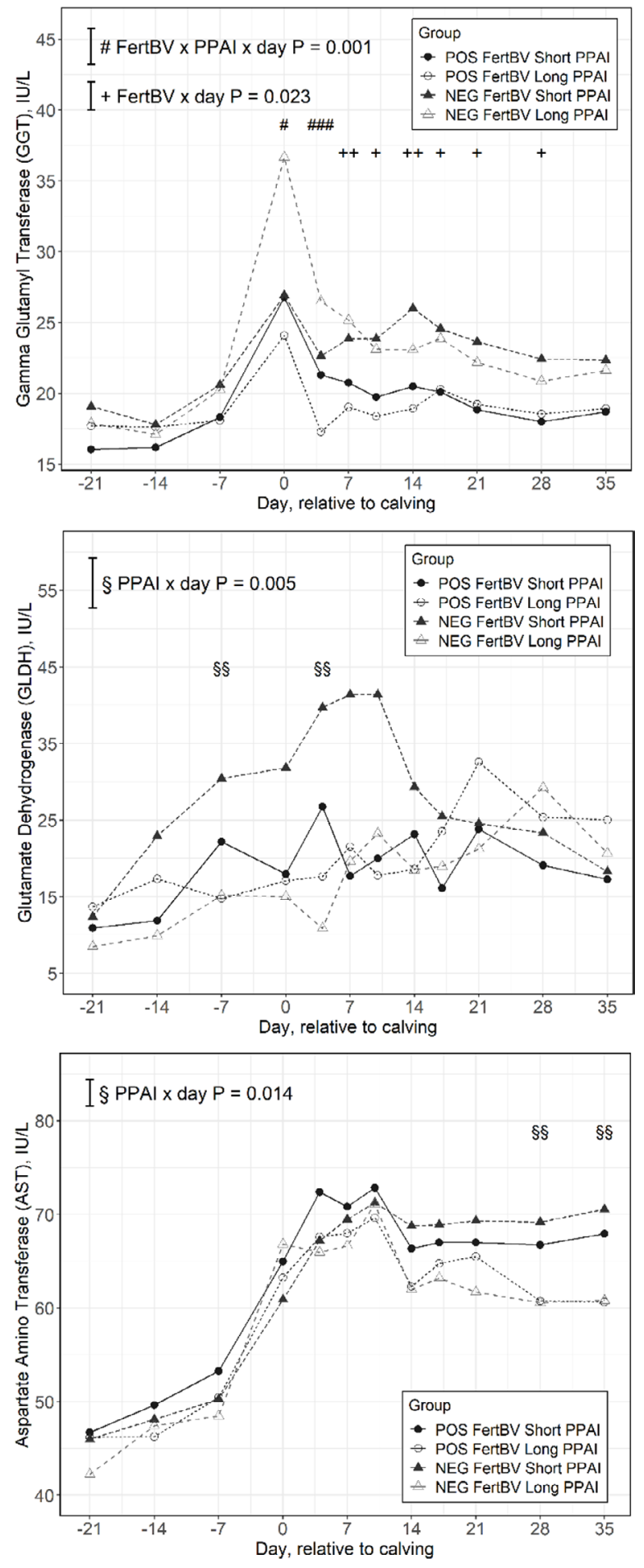

Figure 3. Average concentrations of $\gamma$-glutamyl transferase (GGT), glutamate dehydrogenase (GLDH), and aspartate aminotransferase (AST) from $21 \mathrm{~d}$ precalving to $35 \mathrm{~d}$ postcalving from dairy cows with either a positive (POS) or negative (NEG) fertility breeding value (FertBV) and with either a short (19-35 d), or long (66-131 d) postpartum anestrous interval (PPAI). Error bars represent twice the maximum standard error of the difference (SED). Symbols used for significant effects at a given time point include + for FertBV effects, $\S$ for PPAI effects and \# for interactions of FertBV and PPAI with 1 symbol $=P<0.05,2$ symbols $=P<0.01$, and 3 symbols $=P<0.001$. 

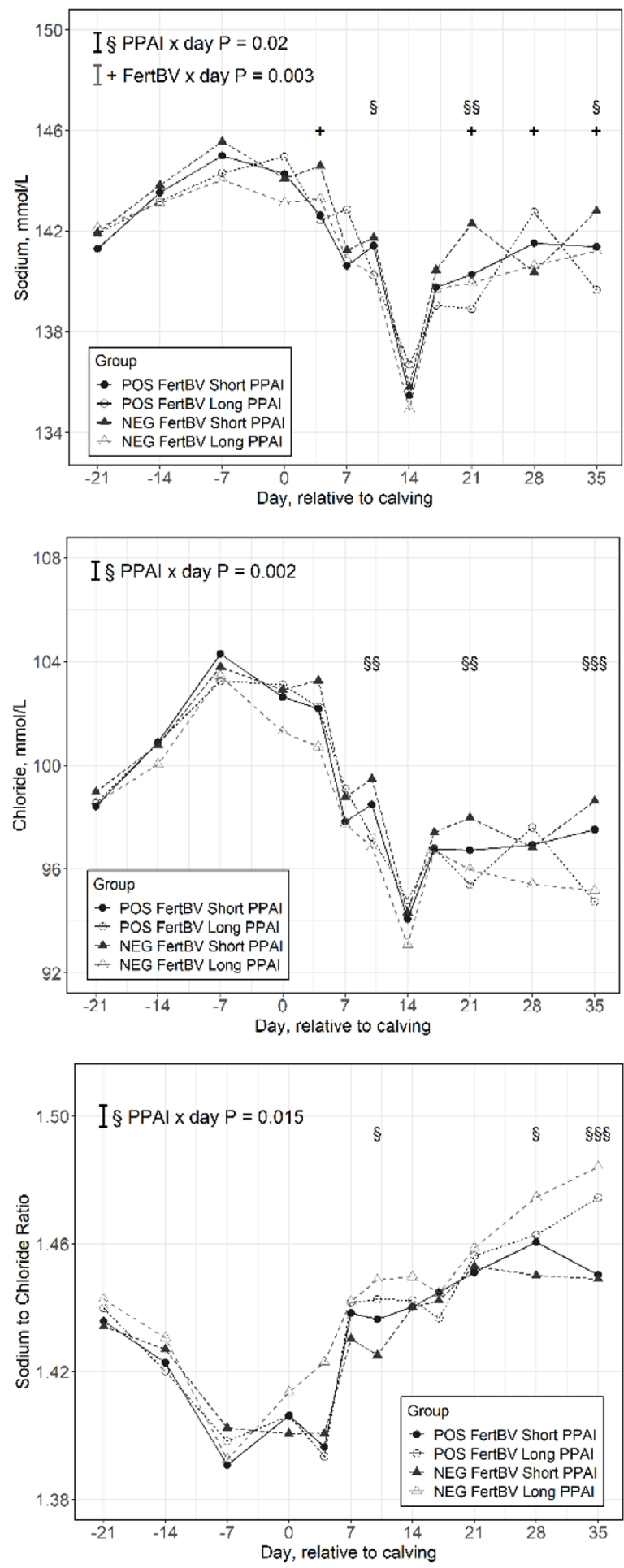

Figure 4. Average concentrations of sodium, chloride, and the sodium-to-chloride ratio from $21 \mathrm{~d}$ precalving to $35 \mathrm{~d}$ postcalving from dairy cows with either a positive (POS) or negative (NEG) fertility breeding value (FertBV) and with either a short (19-35 d), or long (66-131 d) postpartum anestrous interval (PPAI). Error bars represent twice the maximum standard error of the difference (SED). Symbols used for significant effects at a given time point include + for FertBV effects and $\S$ for PPAI effects with 1 symbol $=P<0.05,2$ symbols $=P<0.01$, and 3 symbols $=P<0.001$. ated with delays to the resumption of estrous, such as a longer PPAI (Walsh et al., 2007; Santos et al., 2009; Ospina et al., 2010). Further, when the temporal profile of plasma NEFA and BHB were examined in the subset of cows, there were no differences detected between short and long PPAI groups. It is possible that this population did not experience a large enough negative energy balance to negatively affect cyclicity. By select-
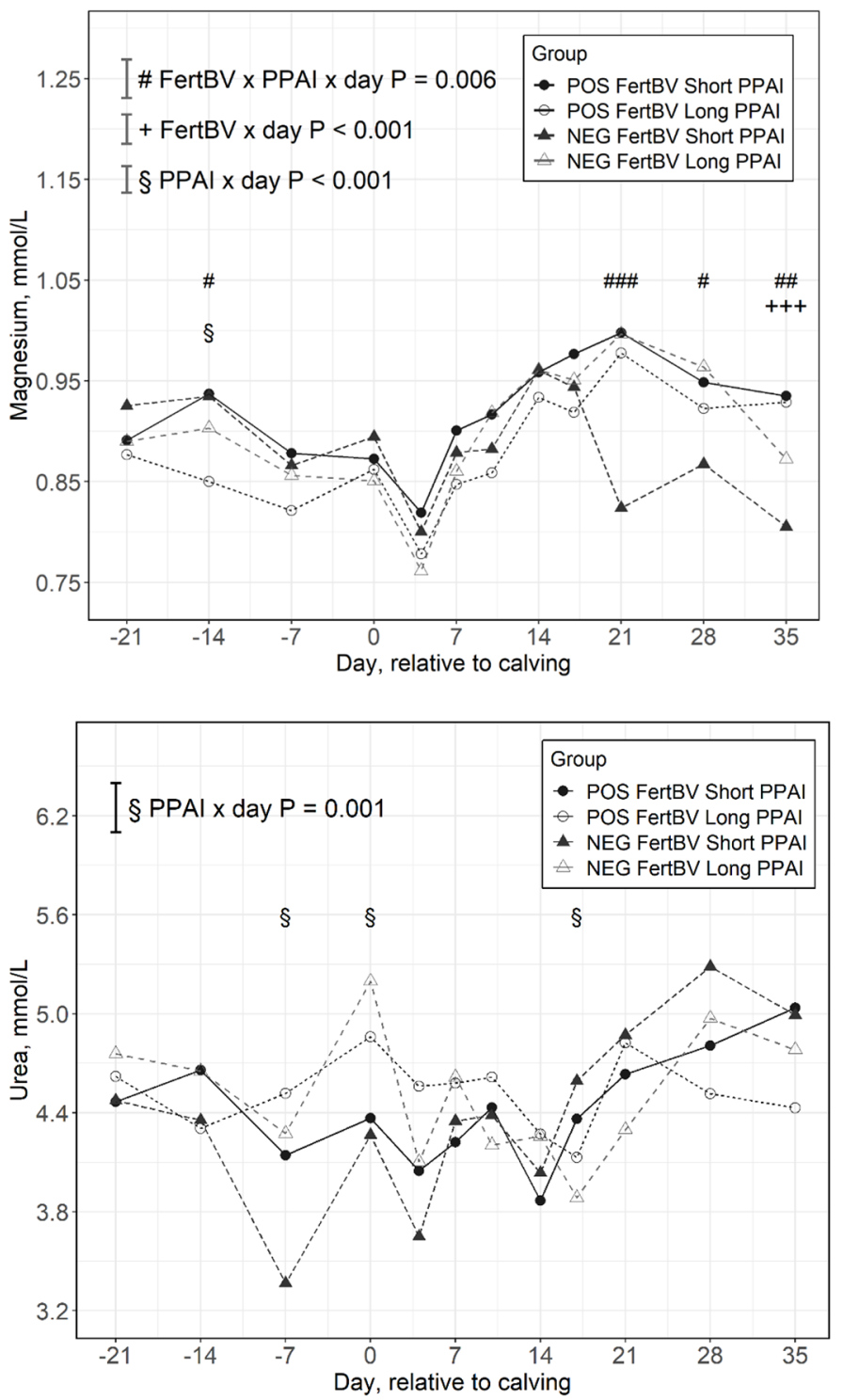

Figure 5. Average concentrations of magnesium and urea from 21 $\mathrm{d}$ pre-calving to $35 \mathrm{~d}$ postcalving from dairy cows with either a positive (POS) or negative (NEG) fertility breeding value (FertBV) and with either a short (19-35 d), or long (66-131 d) postpartum anestrous interval (PPAI). Error bars represent twice the maximum standard error of the difference (SED). Symbols used for significant effects at a given time point include + for FertBV effects, $\S$ for PPAI effects and \# for interactions of FertBV and PPAI with 1 symbol $=P<0.05,2$ symbols $=P<0.01$, and 3 symbols $=P<0.001$. 
ing to profile the long PPAI cows, which had the lowest mean NEFA at $\mathrm{d} 7$ in the full herd, rather than the very long PPAI cows, we may have limited our ability to detect metabolic imbalance associated with PPAI length. A BCS loss over 1.2 units of a 5-point scale (Aungier et al., 2014), which is equivalent to 2.5 BCS units of a 10-point scale (Roche et al., 2004), has been associated with a decreased probability of resuming ovulation by any given time postpartum by $62 \%$; however, in the current study, BCS loss was, on average, less than 1.2 units across the study period. This is further supported by mean group BHB concentrations never rising over $1.3 \mathrm{mmol} / \mathrm{L}$, and liver TAG concentrations not differing between PPAI groups in the whole herd indicating a lack of maladaptation to lactation. Our results indicate that this population of primiparous cows adapted to the transition into lactation without severe metabolic dysfunction, which may be limiting our ability to detect metabolic effects on PPAI.

The plasma metabolic profiles differed between POS and NEG cows, both pre- and postcalving. Initial analysis of postcalving plasma NEFA and BHB concentrations across the full herd indicated that metabolic differences during the first 2 wk postcalving were associated with FertBV rather than the resumption of estrous, with lower concentrations observed in NEG cows. The detailed temporal analyses in the subset of cows then revealed that there were lower mean NEFA and BHB concentrations in NEG cows than POS cows across the entire transition period. If differences in FertBV were associated with major differences in milk production and transition period health it would be expected that NEG FertBV cows would have higher milk production, and greater NEFA and BHB concentrations than POS FertBV cows; however, average NEFA and $\mathrm{BHB}$ were lower across the transition period, and in the full herd, milk solids yield tended to be lower in NEG FertBV cows in the first month (Meier et al., 2021a). Although there were no significant interactions with time, BHB concentrations in NEG cows appeared to be numerically the lowest precalving. Furthermore, the albumin-to-globulin ratio was also greater in NEG cows than POS FertBV cows precalving, indicative of improved liver function in NEG cows. Greater albuminto-globulin ratios precalving have been previously reported in cows that calved at a targeted BCS (5 units) compared with higher or lower BCS (Roche et al., 2013; Akbar et al., 2015) and in cows that have a lower PMN count postcalving (Burke et al., 2010), which indicate that a high albumin-to-globulin ratio is a positive marker of liver health. In the current study, the greater albumin-to-globulin ratio in NEG cows precalving was most likely caused by slightly lower globulin concentra- tions. Plasma globulin concentrations are lower in cows that calve at an optimal BCS and naturally decrease in late pregnancy (Piccione et al., 2011; Akbar et al., 2015). Bilirubin concentrations were also lower in NEG cows across the entire transition period. As bilirubin clearance is facilitated by liver activity, decreased liver function results in increased bilirubin concentrations in the blood (Tennant and Center, 2014). Therefore, the lower BHB and bilirubin in NEG cows, coupled with their greater albumin-to-globulin ratio, support improved prepartum hepatic health compared with POS cows.

Nevertheless, despite their better metabolic status precalving, NEG cows responded to calving with a sustained increase in GGT concentrations relative to POS cows, with differences still apparent at d 28 postcalving. However, because absolute GGT concentrations were still low and within published reference intervals (Cozzi et al., 2011; Bossaert et al., 2012; Kawashima et al., 2016; Moretti et al., 2017) postcalving, we propose they do not indicate a high degree of liver stress in NEG cows. Further, this sustained increase in GGT is unlikely to be in response to hepatic processing of NEFA, as both NEFA and BHB concentrations were lower in NEG cows, leading us to conclude that it is unlikely there is liver damage. It cannot be concluded from this study if these effects would also be present in multiparous cows, or if additional calving events and lactations would highlight additional differences between POS and NEG cows.

The NEG L-PPAI cows had elevated GGT whereas NEG S-PPAI had elevated GLDH across the transition period indicative of hepatic stress. Concentrations of GGT peaked on the day of calving for all groups, but NEG L-PPAI cows had the greatest concentrations of GGT. Both the POS and the NEG S-PPAI groups of cows had GGT peaks of about $25 \mathrm{IU} / \mathrm{L}$; however, in the NEG L-PPAI cows, GGT concentration peaks at $37 \mathrm{IU} / \mathrm{L}$, over $30 \%$ greater. These cows did not differ in any other metabolite around calving, so it appears to be an acute response to the calving event. Reference intervals for GGT range from 12 to $35 \mathrm{IU} / \mathrm{L}$ (Cozzi et al., 2011; Bossaert et al., 2012; Kawashima et al., 2016; Moretti et al., 2017), so a peak of $37 \mathrm{IU} / \mathrm{L}$ is not indicative of a high level of liver damage. The NEG S-PPAI cows also had an altered hepatic activity profile, albeit in a different manner to NEG L-PPAI cows, whereby they had the greatest mean GLDH concentrations during the transition period. Aungier et al. (2014) also report positive effects of high GLDH concentrations on uterine involution postcalving, as cows with shorter involution intervals had greater GLDH concentrations on the day of calving than those with longer periods from 
calving to uterine involution. Therefore, the increased GLDH concentrations in NEG S-PPAI cows may be a mechanism behind the short PPAI. Although markers of hepatic stress were increased in NEG FertBV cows, these are unlikely to indicate liver damage, and interactions with PPAI length indicate a possible mechanism supportive of uterine repair.

Another finding of interest was the reduced concentration of $\mathrm{Mg}$ from d 21 onwards in NEG S-PPAI cows. Cows that cycle by 6 wk postcalving have greater $\mathrm{Mg}$ concentrations from $1 \mathrm{wk}$ precalving until $6 \mathrm{wk}$ postcalving (Jeong et al., 2015). Additionally, greater $\mathrm{Mg}$ concentrations $4 \mathrm{wk}$ postcalving increased the probability of the resumption of ovulation postcalving (Aungier et al., 2014), highlighting the importance of $\mathrm{Mg}$ in supporting the resumption of estrous. However, in the current study, the similar $\mathrm{Mg}$ concentrations in POS S-PPAI and POS L-PPAI indicate that $\mathrm{Mg}$ is not a limiting factor in POS FertBV cows. The $\mathrm{Mg}$ concentrations do not change over an estrous cycle in serum or uterine fluid (Alavi-Shoushtari et al., 2012), but do in the saliva of buffalos (Devi et al., 2016). As there were also no differences between POS and NEG cows with long PPAI, it is possible that NEG cows may be responding to the metabolic requirements of estrous differently than POS cows.

There were other multiple effects after d 14 postcalving on muscle enzymes and electrolytes that may also be the result of estrous events. Concentrations of AST at $\mathrm{d} 28$ and 35 postcalving were lower in cows that had a long PPAI than cows that had a short PPAI, who had returned to estrous around this time. Blood profiles of beef heifers in a nonestrous state have lower concentrations of AST compared with heifers in estrous (Crane et al., 2016). In goats, AST concentrations were greater at the beginning and end of a cycle and were associated with progesterone concentrations (Yaqub et al., 2013). Increased AST plasma concentrations can be a marker of either liver or muscle damage, and has been proposed to be linked to the increased physical activity that occurs during estrous (Crane et al., 2016). Other electrolytes measured also had concentrations that fluctuated over this time, including $\mathrm{Na}, \mathrm{Cl}$, and bicarbonate. Sodium concentrations rise postestrus and then drop from d 7 to a nadir around d 19 of the estrous cycle in lactating cows (Roussel et al., 1983) and have been reported to be lower in beef heifers in estrus (Crane et al., 2016). In the current trial, cows that had a short PPAI had greater sodium and chloride concentrations and a lower sodium to chloride ratio than those that had a long PPAI. Therefore, we hypothesize that the changes reported with the short PPAI may reflect the physiological changes associated with estrus events occurring during the sampling period.

\section{CONCLUSIONS}

Primiparous cows with NEG FertBV have an altered metabolic response compared with those with POS FertBV. Body tissue mobilization, hepatic responses to calving, and electrolyte balance were all altered. However, these differences were within reference ranges for a healthy transition and were consistent with small differences in BCS, BW, and milk production (Meier et al., 2021a), which, in turn, were consistent with the differences in the estimated breeding values for these traits. Although this study only focused on primiparous animals, we conclude that the profound differences in reproductive performance among the groups after their first calving (Meier et al., 2021a) was not explained by underlying differences in metabolic responses during the transition period.

\section{ACKNOWLEDGMENTS}

We acknowledge the DairyNZ Ltd. (Hamilton, New Zealand) technical and farm teams' invaluable support during this study. In particular, Stuart Morgan, Kate Watkins, and Dagmar Elliott were pivotal in the phenotyping. The management and farm team at AgResearch's Tokanui Research Farm (Tokanui, New Zealand) also supported this work by managing the animals. Livestock Improvement (LIC, Hamilton, New Zealand) and the New Zealand Animal Evaluation Limited are thanked for providing data for this study. This work was funded by NZ dairy farmers through DairyNZ Incorporated and by the Ministry of Business, Innovation, and Employment (grant number DRCX1302). We are grateful for dairy farmers' support and contribution, along with LIC and CRV Ambreed, when establishing this research herd. The authors have not stated any conflicts of interest.

\section{REFERENCES}

Akbar, H., T. M. Grala, M. Vailati Riboni, F. C. Cardoso, G. Verkerk, J. McGowan, K. Macdonald, J. Webster, K. Schutz, S. Meier, L. Matthews, J. R. Roche, and J. J. Loor. 2015. Body condition score at calving affects systemic and hepatic transcriptome indicators of inflammation and nutrient metabolism in grazing dairy cows. J. Dairy Sci. 98:1019-1032. https://doi.org/10.3168/jds.2014-8584.

Alavi-Shoushtari, S. M., S. Asri-Rezaie, R. Abedizadeh, A. Khaki, M. Pak, and S. Alizadeh. 2012. Calcium and magnesium concentrations in uterine fluid and blood serum during the estrous cycle in the bovine. Vet. Res. Forum 3:137-141.

Aungier, S. P. M., J. F. Roche, M. G. Diskin, and M. A. Crowe. 2014. Risk factors that affect reproductive target achievement in fertile 
dairy cows. J. Dairy Sci. 97:3472-3487. https://doi.org/10.3168/ jds.2013-7404.

Bossaert, P., E. Trevisi, G. Opsomer, G. Bertoni, S. De Vliegher, and J. L. M. R. Leroy. 2012. The association between indicators of inflammation and liver variables during the transition period in high-yielding dairy cows: An observational study. Vet. J. 192:222225. https://doi.org/10.1016/j.tvjl.2011.06.004.

Burke, C. R., S. Meier, S. McDougall, C. Compton, M. Mitchell, and J. R. Roche. 2010. Relationships between endometritis and metabolic state during the transition period in pasture-grazed dairy cows. J. Dairy Sci. 93:5363-5373. https://doi.org/10.3168/jds.2010-3356.

Cozzi, G., L. Ravarotto, F. Gottardo, A. L. Stefani, B. Contiero, L. Moro, M. Brscic, and P. Dalvit. 2011. Short communication: Reference values for blood parameters in Holstein dairy cows: Effects of parity, stage of lactation, and season of production. J. Dairy Sci. 94:3895-3901. https://doi.org/10.3168/jds.2010-3687.

Crane, E. M., J. C. Munro, S. L. Bourgon, M. Diel de Amorim, R. Ventura, A. H. Fredeen, and Y. R. Montanholi. 2016. Metabolic blood profile of beef heifers during oestrous and non-oestrous states. Reprod. Domest. Anim. 51:819-826. https://doi.org/10 $.1111 /$ rda. 12763 .

Cummins, S. B., P. Lonergan, A. C. O. Evans, D. P. Berry, R. D. Evans, and S. T. Butler. 2012. Genetic merit for fertility traits in Holstein cows: I. Production characteristics and reproductive efficiency in a pasture-based system. J. Dairy Sci. 95:1310-1322. https://doi.org/10.3168/jds.2011-4742.

Darwash, A. O., G. E. Lamming, and J. A. Wooliams. 1997. The phenotypic association between the interval to post-partum ovulation and traditional measures of fertility in dairy cattle. Anim. Sci. 65:9-16. https://doi.org/10.1017/S1357729800016234.

Devi, I., P. Singh, S. S. Lathwal, A. Kumaresan, and K. Dudi. 2016. Evaluation of salivary electrolytes during estrous cycle in Murrah buffaloes with reference to estrus detection. Vet. World 9:11571161. https://doi.org/10.14202/vetworld.2016.1157-1161.

Jeong, J. K., I. S. Choi, H. G. Kang, T. Y. Hur, Y. H. Jung, and I. H. Kim. 2015. Relationship between serum metabolites, body condition, peri- and postpartum health and resumption of postpartum cyclicity in dairy cows. Livest. Sci. 181:31-37. https://doi.org/10 .1016/j.livsci.2015.09.022.

Kawashima, C., N. Ito, S. Nagashima, M. Matsui, K. Sawada, F. J. Schweigert, A. Miyamoto, and K. Kida. 2016. Influence of hepatic load from far-off dry period to early postpartum period on the first postpartum ovulation and accompanying subsequent fertility in dairy. J. Reprod. Dev. 62:289-295. https://doi.org/10.1262/jrd .2015-141.

Lucy, M. C., G. A. Verkerk, B. E. Whyte, K. A. Macdonald, L. Burton, R. T. Cursons, J. R. Roche, and C. W. Holmes. 2009. Somatotropic axis components and nutrient partitioning in genetically diverse dairy cows managed under different feed allowances in a pasture system. J. Dairy Sci. 92:526-539. https://doi.org/10.3168/ jds.2008-1421.

Macdonald, K. A., L. R. McNaughton, G. A. Verkerk, J. W. Penno, L. J. Burton, D. P. Berry, P. J. S. Gore, J. A. S. Lancaster, and C. W. Holmes. 2007. A comparison of three strains of Holstein-Friesian cows grazed on pasture: Growth, development, and puberty. J. Dairy Sci. 90:3993-4003. https://doi.org/10.3168/jds.2007-0119.

Macmillan, K. L., V. K. Taufa, D. R. Barnes, A. M. Day, and R. Henry. 1988. Detecting estrus in synchronized heifers-using tailpaint and an aerosol raddle. Theriogenology 30:1099-1114. https://doi .org/10.1016/0093-691X(88)90285-3.

McCarthy, S. D., S. T. Butler, J. Patton, M. Daly, D. G. Morris, D. A. Kenny, and S. M. Waters. 2009. Differences in the expression of genes involved in the somatotropic axis in divergent strains of Holstein-Friesian dairy cows during early and mid lactation. J. Dairy Sci. 92:5229-5238. https://doi.org/10.3168/jds.2008-1856.

Meier, S., B. Kuhn-Sherlock, P. A. Amer, J. R. Roche, and C. R. Burke. 2021a. Positive genetic merit for fertility traits is associated with superior reproductive performance in pasture-based dairy cows with seasonal calving. J. Dairy Sci. 104:10382-10398. https:/ /doi.org/10.3168/jds.2021-20195.
Meier, S., L. R. McNaughton, R. Handcock, P. R. Amer, P. R. Beatson, J. R. Bryant, K. G. Dodds, R. Spelman, J. R. Roche, and C. R. Burke. 2021b. Heifers with positive genetic merit for fertility traits reach puberty earlier and have a greater pregnancy rate than heifers with negative genetic merit for fertility traits. J. Dairy Sci. 104:3707-3721. https://doi.org/10.3168/jds.2020-19155.

Meikle, A., M. Kulcsar, Y. Chilliard, H. Febel, C. Delavaud, D. Cavestany, and P. Chilibroste. 2004. Effects of parity and body condition at parturition on endocrine and reproductive parameters of the cow. Reproduction 127:727-737. https://doi.org/10.1530/rep .1.00080.

Moore, S. G., T. Fair, P. Lonergan, and S. T. Butler. 2014. Genetic merit for fertility traits in Holstein cows: IV. Transition period, uterine health, and resumption of cyclicity. J. Dairy Sci. 97:27402752. https://doi.org/10.3168/jds.2013-7278.

Moretti, P., S. Paltrinieri, E. Trevisi, M. Probo, A. Ferrari, A. Minuti, and A. Giordano. 2017. Reference intervals for hematological and biochemical parameters, acute phase proteins and markers of oxidation in Holstein dairy cows around 3 and 30 days after calving. Res. Vet. Sci. 114:322-331. https://doi.org/10.1016/j.rvsc.2017.06 .012 .

Opsomer, G., Y. T. Gröhn, J. Hertl, M. Coryn, H. Deluyker, and A. de Kruif. 2000. Risk factors for post partum ovarian dysfunction in high producing dairy cows in Belgium: A field study. Theriogenology 53:841-857. https://doi.org/10.1016/S0093-691X(00)00234-X.

Ospina, P. A., D. V. Nydam, T. Stokol, and T. R. Overton. 2010. Associations of elevated nonesterified fatty acids and $\beta$-hydroxybutyrate concentrations with early lactation reproductive performance and milk production in transition dairy cattle in the northeastern United States. J. Dairy Sci. 93:1596-1603. https://doi.org/10.3168/jds .2009-2852.

Piccione, G., V. Messina, A. Schembari, S. Casella, C. Giannetto, and D. Alberghina. 2011. Pattern of serum protein fractions in dairy cows during different stages of gestation and lactation. J. Dairy Res. 78:421-425. https://doi.org/10.1017/S0022029911000562.

Roche, J. R., D. P. Berry, and E. S. Kolver. 2006. Holstein-Friesian strain and feed effects on milk production, body weight, and body condition score profiles in grazing dairy cows. J. Dairy Sci. 89:3532-3543. https://doi.org/10.3168/jds.S0022-0302(06)72393 $-1$.

Roche, J. R., P. G. Dillon, C. R. Stockdale, L. H. Baumgard, and J. M. VanBaale. 2004. Relationships among international body condition scoring systems. J. Dairy Sci. 87:3076-3079. https://doi.org/ 10.3168/jds.S0022-0302(04)73441-4.

Roche, J. R., J. M. Lee, K. A. Macdonald, and D. P. Berry. 2007. Relationships among body condition score, body weight, and milk production variables in pasture-based dairy cows. J. Dairy Sci. 90:3802-3815. https://doi.org/10.3168/jds.2006-740.

Roche, J. R., K. A. Macdonald, K. E. Schütz, L. R. Matthews, G. A. Verkerk, S. Meier, J. J. Loor, A. R. Rogers, J. McGowan, S. R. Morgan, S. Taukiri, and J. R. Webster. 2013. Calving body condition score affects indicators of health in grazing dairy cows. J. Dairy Sci. 96:5811-5825. https://doi.org/10.3168/jds.2013-6600.

Roussel, J. D., T. J. Clement, and T. J. Aranas. 1983. Changes of aldosterone in blood serum of dairy cattle during estrous cycle. J. Dairy Sci. 66:1734-1737. https://doi.org/10.3168/jds.S0022 $-0302(83) 81999-7$.

Santos, J. E. P., H. M. Rutigliano, and M. F. Sá Filho. 2009. Risk factors for resumption of postpartum estrous cycles and embryonic survival in lactating dairy cows. Anim. Reprod. Sci. 110:207-221. https://doi.org/10.1016/j.anireprosci.2008.01.014.

Senatore, E. M., W. R. Butler, and P. A. Oltenacu. 1996. Relationships between energy balance and post-partum ovarian activity and fertility in first lactation dairy cows. Anim. Sci. 62:17-23. https://doi.org/10.1017/S1357729800014260.

Tennant, B. C., and S. A. Center. 2014. Liver Function. 3rd ed. J.J. Kaneko, ed. Academic Press.

Veronese, A., O. Marques, R. Moreira, A. L. Belli, R. S. Bisinotto, T. R. Bilby, F. Peñagaricano, and R. C. Chebel. 2019a. Genomic merit for reproductive traits. I: Estrous characteristics and fertility 
in Holstein heifers. J. Dairy Sci. 102:6624-6638. https://doi.org/10 $.3168 /$ jds.2018-15205.

Veronese, A., O. Marques, F. Peñagaricano, R. S. Bisinotto, K. G. Pohler, T. R. Bilby, and R. C. Chebel. 2019b. Genomic merit for reproductive traits. II: Physiological responses of Holstein heifers. J. Dairy Sci. 102:6639-6648. https://doi.org/10.3168/jds.2018 -15245 .

Walsh, R. B., J. S. Walton, D. F. Kelton, S. J. LeBlanc, K. E. Leslie, and T. F. Duffield. 2007. The effect of subclinical ketosis in early lactation on reproductive performance of postpartum dairy cows. J. Dairy Sci. 90:2788-2796. https://doi.org/10.3168/jds.2006-560.

Wathes, D. C., M. Fenwick, Z. Cheng, N. Bourne, S. Llewellyn, D. G. Morris, D. Kenny, J. Murphy, and R. Fitzpatrick. 2007. Influence of negative energy balance on cyclicity and fertility in the high producing dairy cow. Theriogenology 68(Suppl 1):S232-S241. https://doi.org/10.1016/j.theriogenology.2007.04.006.

Westwood, C. T., I. J. Lean, and J. K. Garvin. 2002. Factors influencing fertility of Holstein dairy cows: A multivariate description.
J. Dairy Sci. 85:3225-3237. https://doi.org/10.3168/jds.S0022 -0302(02)74411-1.

Yaqub, L. S., M. U. Kawu, S. Ambali, and H. Buhari. 2013. Effect of estrous cycle on serum electrolytes and liver enzymes in Red Sokoto goats. Afr. J. Biochem. Res. 7:174-178.

\section{ORCIDS}

T. M. Grala $\odot$ https://orcid.org/0000-0001-9897-8194

B. Kuhn-Sherlock () https://orcid.org/0000-0002-1890-0301

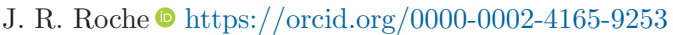

O. M. Jordan (1) https://orcid.org/0000-0002-1361-7777

C. V. C. Phyn (1) https://orcid.org/0000-0002-4912-4069

C. R. Burke (ㄴ) https://orcid.org/0000-0003-3868-8675

S. Meier (1) https://orcid.org/0000-0002-4386-7734 